\title{
Meningkatkan Hasil Belajar Bahasa Indonesia Dengan Menerapkan Model Pengajaran Kolaborasi Pada Siswa Kelas VII SMP Negeri 3 Palopo
}

\author{
Ramalia Sapa' \\ SMP Negeri 3 Palopo \\ +62 821-9029-7597
}

\section{Abstrak}

Penelitian ini bertujuan untuk mengekplorasi peningkatan hasil belajar siswa kelas VII SMP Negeri 3 Palopo dalam mempelajari Bahasa Indonesia khususnya pada pokok bahasan menceritakan peristiwa yang dilihat atau dialami. Penelitian ini merupakan penelitian tindakan kelas dengan menggunakan dua siklus. Setiap siklus dilaksanakan sebanyak tiga kali pertemuan. Data observasi siswa dan guru dianalisis secara kualitatif dengan menggunakan lembar observasi keaktifan siswa dan guru. Berdasarkan hasil analisis data dan pembahasan hasil penelitian, dapat disimpulkan bahwa penerapan model kolaborasi dapat meningkatkan hasil belajar bahasa Indonesia siswa kelas VII SMP Negeri 3 Palopo Kota Palopo. Perencanaan tindakan melalui penerapan model kolaborasi yang dilakukan guru dan peneliti secara kolaborasi sudah maksimal. Pada tahap pelaksanaan pembelajaran, guru menerapkan model pengajaran kolaborasi dengan tepat sehingga hasil belajar bahasa indonesia siswa dapat meningkat. Peningkatan keterampilan siswa tersebut dapat terlihat baik dalam proses belajar mengajar, hasil tes siswa yang telah dievaluasi guru dan peneliti menunjukkan kemajuan yang menggembirakan bagi proses pengajaran dengan menerapkan pengajaran kolaborasi pada siswa kelas VII SMP Negeri 3 Palopo Kota Palopo. Penulis menyampaikan saran sebagai berikut: (1) Siswa antusias mengikuti pelajaran serta Siswa memperhatikan guru saat menjelaskan dari awal samapai akhir pembelajaran; (2) Guru harus mampu menentukan atau memilih topik yang benar-benar bisa diterapkan dalam proses belajar mengajar sehingga diperoleh hasil yang optimal; (3) Pihak sekolah sebaiknya menyediakan fasilitas guru harus mampu menentukan atau memilih topik yang benar-benar bisa diterapkan dalam proses belajar mengajar sehingga diperoleh hasil yang optimal.pembelajaran yang memadai; dan (4) Peneliti lanjut dapat menjadikan hasil penelitian ini sebagai acuan penelitian yang relevan berikutnya. Kesimpulan dari penelitian ini adalah pembelajaran dengan model kolaborasidapat berpengaruh positif terhadap Hasil Belajar dan motivasi belajar Siswa, serta model pembelajaran ini dapat digunakan sebagai salah satu alternatif pembelajaran.

Kata Kunci: hasil belajar, kolaborasi, pembelajaran bahasa

\section{Pendahuluan}

Pada hakekatnya kegiatan belajar mengajar adalah suatu proses interaksi atau hubungan timbal balik antara guru dan siswa dalam satuan pembelajaran. Guru sebagai salah satu komponen dalam proses belajar menganjar merupakan pemegang peran yang sangat penting. Guru bukan hanya sekedar penyampai materi saja, tetapi lebih dari itu guru dapat dikatakan sebagai sentral pembelajaran. 
Sebagai pengatur sekaligus pelaku dalam proses belajar mengajar, gurulah yang mengarahkan bagaimana proses belajar mengajar itu dilaksanakan. Karena itu guru harus dapat membuat suatu pengajaran menjadi lebeh efektif juga menarik sehingga bahan pelajaran yang disampaikan akan membuat siswa merasa senang dan merasa perlu untuk mempelajari bahan pelajaran tersebut.

Berhasilnya tujuan pembelajaran ditentukan oleh banyak faktor diantaranya adalah faktor guru dalam melaksanakan proses belajar mengajar, karena guru secara langsung dapat mempengaruhi, membina dan meningkatkan kecerdasan serta keterampilan siswa. Untuk mengatasi permasalahan di atas dan guna mencapai tujuan pendidikan secara maksimal, peran guru sangat penting dan diharapkan guru memiliki cara/model mengajar yang baik dan mampu memilih model pembelajaran yang tepat dan sesuai dengan konsep-konsep mata pelajaran yang akan disampaikan.

Model pembelajaran jenisnya beragam yang masing-masing memiliki kelebihan dan kelemahan, maka pemilihan model yang sesuai dengan topik atau pokok bahasan yang akan diajarkan harus betul-betul dipikirkan oleh guru yang akan menyampaikan materi pelajaran. Sedangkan penggunaan model pengajaran kolaborasi diharapkan dapat meningkatkan aktivitas siswa dalam proses belajar mengajar sehingga dalam proses belajar mengajar itu aktivitasnya tidak hanya didominasi oleh guru, dengan demikian siswa akan terlibat secara fisik, emosional dan intelektual.

\section{Model Pembelajaran Kolaborasi}

Pembelajaran kolaboratif (Colaborative Learning) merupakan model pembelajaran yang menerapkan paradigma baru dalam teori-teori belajar (Yufiarti: 2003) (dalam Sulhan, 2006:69). Pendekatan ini dapat digambarkan sebagai suatu model pembelajaran dengan menumbuhkan para siswa untuk bekerja sama dalam kelompok-kelompok kecil untuk mencapai tujuan yang sama.

Pendekatan kolaboratif bertujuan agar siswa dapat membangun pengetahunnya melalui dialog, saling membagi informasi sesama siswa dan guru sehingga siswa dapat meningkatkan kemampuan mental pada tingkat tinggi. Model ini digunakan pada setiap mata pelajaran terutama yang mungkin berkembangkan sharing of information di antara siswa.

Belajar kolaboratif digambarkan sebagai suatu model pengajaran yang mana para siswa bekerja sama dalam kelompok-kelompok kecil untuk mencapai tujuan yang sama. Hal yang perlu diperhatikan dalam kegiatan belajar kolaboratif, para siswa bekerja sama menyelesaikan masalah yang sama, dan bukan secara individual menyelesaikan bagian-bagian yang terpisah dari masalah tersebut. Dengan demikian, selama berkolaborasi para siswa bekerja sama membangun pemahaman dan konsep yang sama menyelesaikan setiap bagian dari masalah atau tugas tersebut.

Pendekatan kolaboratif dipandang sebagai proses membangun dan mempertahankan konsepsi yang sama tentang suatu masalah. Dari sudut pandang ini, model belajar kolaboratif menjadi efisien karena para anggota kelompok belajar dituntut untuk berpikir secara interaktif. Para ahli berpendapat bahwa berpikir bukanlah sekedar memanipulasi objek-objek mental, melainkan juga interaksi dengan oran glain dan dengan lingkungan.

Dalam kelas yang menerapkan model kolaboratif, guru membagi otoritas dengan siswa dalam berbagai cara khusus. Guru mendorong siswa untuk menggunakan pengetahun mereka, menghormati rekan kerjanya, dan memfokuskan diri pada pemahaman tingkat tinggi. 
Peran guru dalam model pembelajaran kolaboratif adalah sebagai mediator. Guru menghubungkan informasi baru terhadap pengalaman siswa dengan proses belajar di bidang lain, membantu siswa menentukan apa yang harus dilakukan jika siswa mengalami kesulitan, dan membantu mereka belajar tentang bagaimana caranya belajar. Lebih dari itu, guru sebagai mediator menyesuaikan tingkat informasi siswa dan mendorong agar siswa memaksimalkan kemampuannya untuk bertanggung jawab atas proses belajar mengajar selanjutnya.

Peran sebagai model dapat diwujudkan dengan cara membagi pikiran tentang suatu hal (thinking aloud) atau menunjukkan pada siswa tentang bagaimana melakukan sesuatu secara bertahap (demonstrasi) (Sulhan, 206:70-71) Di samping itu, menunjukkan pada siswa bagaimana cara berpikir sewaktu melalui situasi kelompok yang sulit dan melalui masalah komunikasi adalah sama pentingnya dengan mencontohkan bagaimana cara membuat perencanaan, memonitor penyelesaian tugas, dan mengukur apa yang sudah dipelajari.

Salah satu ciri penting dari kelas yang menerapkan model pembelajaran kolaboratif adalah siswa tidak dikotak-kotakan berdasarkan kemampuannya, minatnya, ataupun karakteristik lainnya. Pengkotakan tersebut dinilai menghambat munculnya kolaborasi dan mengurangi kesempatan siswa untuk belajar bersama siswa lain. Dengan demikian, semua siswa dapat belajar dari siswa lain dan tidak ada siswa yang tidak mempunyai kesempatan untuk memberikan masukan dan menghargai masukan yang diberikan orang lain.

Berdasarkan latar belakang di atas, tujuan dalam penelitian ini dapat dioperasionalkan sebagai berikut: 1). untuk memperoleh deskripsi tentang peningkatan hasil belajar siswa kelas VII SMP Negeri 3 Palopo Kota Palopo dalam mempelajari Bahasa Indonesia khususnya pada pokok bahasan menceritakan peristiwa yang dilihat atau dialami; dan 2). untuk meningkatkan aktifitas dan hasil belajar bahasa Indonesia pada siswa kelas VII SMP Negeri 3 Palopo Kota Palopo.

\section{Metode Penelitian}

Penelitian ini merupakan penelitian tindakan (action research classroom), karena penelitian dilakukan untuk memecahkan masalah pembelajaran di kelas. Dalam penelitian ini guru merupakan peneliti, di mana guru sangat berperan sekali dalam proses penelitian tindakan kelas. Dalam bentuk ini, tujuan utama penelitian tindakan kelas ialah untuk meningkatkan praktik-praktik pembelajaran di kelas. Dalam kegiatan ini, guru terlibat langsung secara penuh dalam proses perencanaan, tindakan, observasi, dan refleksi. Kehadiran pihak lain dalam penelitian ini peranannya tidak dominan dan sangat kecil.

Penelitian ini mengacu pada perbaikan pembelajaran yang berkesinambungan. Kemmis dan Taggart (1988:14) (dalam Arikunto, 2002: 83), menyatakan bahwa model penelitian tindakan adalah berbentuk spiral. Tahapan penelitian tindakan pada suatu siklus meliputi perencanaan atau pelaksanaan observasi dan refleksi. Siklus ini berlanjut dan akan dihentikan jika sesuai dengan kebutuhan dan dirasa sudah cukup.

\section{Prosedur Penelitian}

Penelitian ini dilaksanakan dalam dua siklus. Setiap siklus dilaksanakan sebanyak dua kali pertemuan ( 4 x 40 menit). Model siklus yang digunakan dalam penelitian ini dapat dicermati pada gambar berikut. 


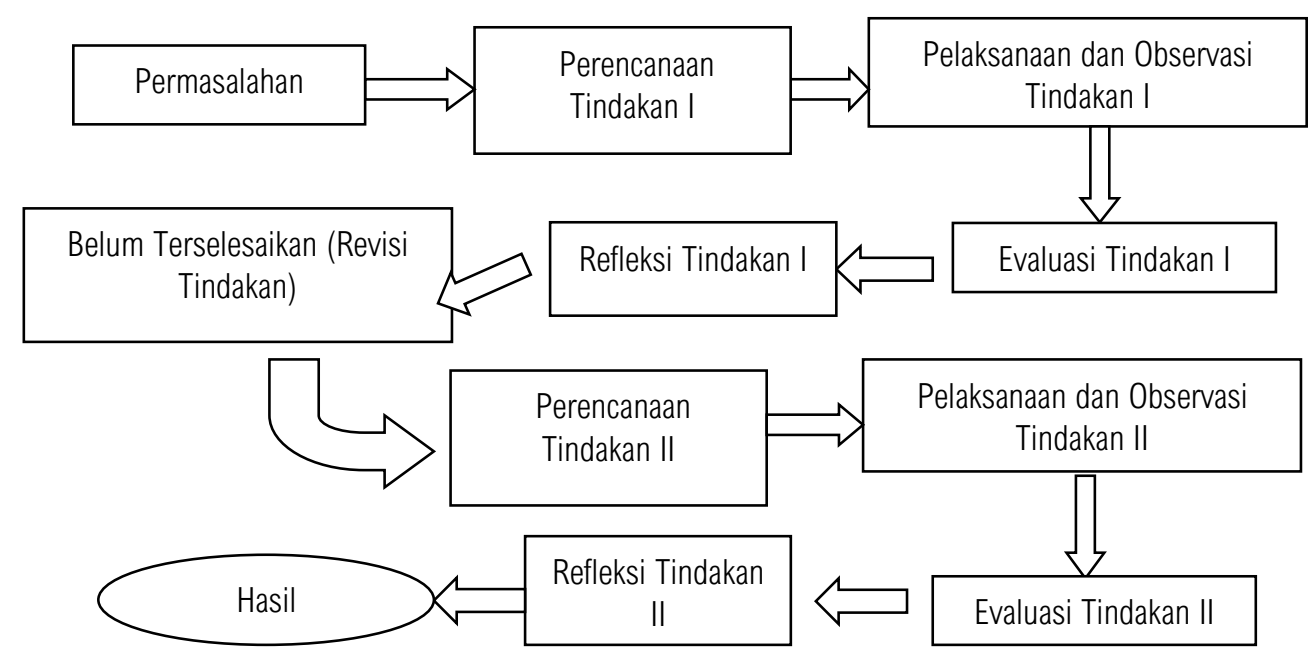

Gambar 1. Alur Penelitian Tindakan Kelas

\section{Siklus I}

\section{Tahap Perencanaan}

Pada tahap ini peneliti mempersiapkan perangkat pembelajaran yang terdiri dari rencana pelajaran 1, LKS 1, soal tes formatif 1 dan alat-alat pengajaran yang mendukung.

\section{Tahap Pelaksanaan dan Observasi}

Pelaksanaan kegiatan belajar mengajar untuk siklus I dilaksanakan sebanyak dua kali pertemuan. Dalam hal ini peneliti bertindak sebagai guru. Adapun proses belajar mengajar mengacu pada rencana pelajaran yang telah dipersiapkan. Pengamatan (observasi) dilaksanakan bersamaan dengan pelaksaaan belajar mengajar. Pada akhir proses belajar mengajar siswa diberi tes formatif I dengan tujuan untuk mengetahui tingkat keberhasilan siswa dalam proses belajar mengajar yang telah dilakukan.

\section{Tahap Evaluasi}

Pada tahap evaluasi, peneliti dan guru memeriksa hasil tes kemampuan siswa yang dikerjakan secara berkolaborasi.

\section{Tahap Refleksi}

Hasil yang didapatkan pada tahap evaluasi menentukan kelanjutan penelitian pada siklus berikutnya. Apabila hasil kemampuan siswa pada siklus I belum menunjukkan peningkatan, akan dilakukan siklus N. Hal-hal yang masih kurang akan diperbaiki dan hasil yang sudah baik akan ditingkatkan pada siklus N. Hasil analisis siklus I inilah yang menjadi acuan peneliti dan guru untuk merencanakan siklus $\mathrm{N}$ sehingga hasil yang akan dicapai pada siklus berikutnya sesuai dengan yang diharapkan dan lebih baik daripada siklus sebelumnya.

\section{Siklus $N$}

\section{Tahap Perencanaan}

Pada tahap ini peneliti mempersiapkan perangkat pembelajaran yang terdiri dari rencana pelajaran 2, LKS 2, soal tes formatif 2 dan alat-alat pengajaran yang mendukung.

\section{Tahap Pelaksanaan dan Observasi}


Pelaksanaan kegiatan belajar mengajar untuk siklus $\mathrm{N}$ dilaksanakan sebanyak dua kali pertemuan. Dalam hal ini peneliti bertindak sebagai guru. Adapun proses belajar mengajar mengacu pada rencana pelajaran dengan memperhatikan revisi pada siklus I, sehingga kesalahan tidak terulang lagi pada siklus N. Pengamatan (observasi) dilaksanakan bersamaan dengan pelaksanaan belajar mengajar.

Pada akhir proses belajar mengajar siswa diberi tes formatif $\mathrm{N}$ dengan tujuan untuk mengetahui tingkat keberhasilan siswa dalam proses belajar mengajar yang telah dilakukan. Instrumen yang digunakan adalah tes formatif N. Tahap Evaluasi

Pada tahap evaluasi, peneliti dan guru memeriksa hasil tes kemampuan siswa yang dikerjakan secara berkolaborasi.

\section{Tahap Refleksi}

Hasil yang didapatkan pada tahap evaluasi menentukan kelanjutan penelitian pada siklus berikutnya. Apabila hasil belajar kemampuan siswa pada siklus $\mathrm{N}$ masih belum menunjukkan peningkatan, akan dilakukan siklus berikutnya. Hal-hal yang masih kurang akan diperbaiki dan hasil yang sudah baik akan ditingkatkan pada siklus berikutnya. Hasil analisis siklus $\mathrm{N}$ inilah yang menjadi acuan penulis untuk merencanakan siklus berikutnya sehingga hasil yang akan dicapai pada siklus berikutnya sesuai dengan yang diharapkan dan lebih baik daripada siklus sebelumnya.

\section{Instrumen Penelitian}

Dalam penelitian tindakan ini, peneliti bertindak sebagai instrumen yang menggunakan teknik tes formatif kemampuan belajar bahasa Indonesia dengan menerapkan model pengajaran kolaborasi.

\section{Teknik Pengumpulan Data}

Sumber data dalam penelitian ini adalah siswa kelas VII SMP Negeri 3 Palopo Kota Palopo. Data yang dikumpulkan yaitu hasil tes kemampuan siswa dan hasil observasi kegiatan siswa dan guru dalam proses pembelajaran Bahasa Indonesia. Adapun teknik pengumpulan data yang digunakan dalam penelitian tindakan kelas ini adalah tes dan observasi.

Dalam teknik tes diperoleh data deskriptif peningkatan keterampilan kemampuan siswa yang diambil dari tes bahasa Indonesia model kolaboratif. Tes ini dirancang oleh peneliti dan guru mata pelajaran. Dalam teknik observasi diperoleh data kualitatif mengenai situasi belajar mengajar pada saat pelaksanaan tindakan yang diambil dengan menggunakan lembar observasi siswa dan guru.

\section{Teknik Analisis Data}

Data penelitian ini dianalisis secara kualitatif. Analisis data kualitatif disajikan dengan mendeskripsikan hasil observasi siswa dan guru, sedangkan analisis kuantitatif digunakan analisis deskriptif yakni membuat daftar skor hasil tes kemampuan siswa. Hasil tes tersebut diperiksa berdasarkan aspek penilaian penulisan cerpen yang telah disusun peneliti dan guru berdasarkan model pengajaran kolaborasi. Skor hasil kemampuan siswa dikategorisasikan dengan menggunakan penentuan patokan dengan penghitungan persentase untuk skala lima. 


\section{Hasil Penelitian}

Hasil penelitian yang diuraikan meliputi data tes dan non tes yang diperoleh dari setiap siklus. Data observasi berupa pengamatan pengelolaan belajar dengan model kolaborasi dan pengamatan aktivitas siswa pada akhir pembelajaran, dan data tes formatif siswa pada setiap siklus. Data tes formatif untuk mengetahui peningkatan Hasil Belajar belajar siswa setelah diterapkan belajar dengan model kolaborasi.

\section{Siklus I}

\section{Tahap Perencanaan}

Pada tahap ini peneliti mempersiapkan perangkat pembelajaran yang terdiri dari rencana pelajaran 1, LKS 1, soal tes formatif 1 dan alat-alat pengajaran yang mendukung.

\section{Tahap Kegiatan dan Pelaksanaan}

Pelaksanaan kegiatan belajar mengajar untuk siklus I dilaksanakan sebanyak dua kali pertemuan. Dalam hal ini peneliti bertindak sebagai guru. Adapun proses belajar mengajar mengacu pada rencana pelajaran yang telah dipersiapkan. Pengamatan (observasi) dilaksanakan bersamaan dengan pelaksaaan belajar mengajar.

Pada akhir proses belajar mengajar siswa diberi tes formatif I dengan tujuan untuk mengetahui tingkat keberhasilan siswa dalam proses belajar mengajar yang telah dilakukan. Data hasil penelitian pada siklus I adalah sebagai berikut:

Tabel 1. Distribusi Nilai Tes Pada Siklus I

\begin{tabular}{|c|c|c|c|c|c|c|c|}
\hline \multirow{2}{*}{$\begin{array}{l}\text { No. } \\
\text { Urut }\end{array}$} & \multirow{2}{*}{ Skor } & \multicolumn{2}{|c|}{ Keterangan } & \multirow{2}{*}{$\begin{array}{l}\text { No. } \\
\text { Urut }\end{array}$} & \multirow{2}{*}{ Skor } & \multicolumn{2}{|c|}{ Keterangan } \\
\hline & & $\mathrm{T}$ & TT & & & $T$ & TT \\
\hline 1 & 80 & $\sqrt{ }$ & & 12 & 30 & & $\sqrt{ }$ \\
\hline 2 & 50 & & $\sqrt{ }$ & 13 & 70 & & $\sqrt{ }$ \\
\hline 3 & 80 & $\sqrt{ }$ & & 14 & 80 & $\sqrt{ }$ & \\
\hline 4 & 60 & & $\sqrt{ }$ & 15 & 70 & & $\sqrt{ }$ \\
\hline 5 & 40 & & $\sqrt{ }$ & 16 & 70 & & $\sqrt{ }$ \\
\hline 6 & 80 & $\sqrt{ }$ & & 17 & 70 & & $\sqrt{ }$ \\
\hline 7 & 70 & & $\sqrt{ }$ & 18 & 80 & $\sqrt{ }$ & \\
\hline 8 & 60 & & $\sqrt{ }$ & 19 & 60 & & $\sqrt{ }$ \\
\hline 9 & 70 & & $\sqrt{ }$ & 20 & 80 & $\sqrt{ }$ & \\
\hline 10 & 80 & $\sqrt{ }$ & & 21 & 100 & $\sqrt{ }$ & \\
\hline 11 & 60 & & $\sqrt{ }$ & Jumlah & 710 & 4 & 6 \\
\hline Jumlah & 730 & 4 & 7 & & & & \\
\hline $\begin{array}{l}\text { Jumlah } \\
\text { Jumlah } \\
\text { Rata-Rat }\end{array}$ & $\begin{array}{l}\text { kor } 14 \\
\text { kor M } \\
\text { Skor }\end{array}$ & \multicolumn{2}{|c|}{ Jumlah Skor Maksimal Ideal 2100} & & & & \\
\hline
\end{tabular}

Keterangan:

Rata- rata skor $=\underline{\text { Jumlah skor } \times 100}$

$$
\text { Skor maksimal ideal }
$$

$\begin{array}{ll}\text { T } & : \text { Tuntas } \\ \text { TT } & : \text { Tidak Tuntas } \\ \text { Jumlah siswa yang tuntas } & : 8 \\ \text { Jumlah siswa yang belum tuntas } & : 13 \\ \text { Klasikal } & : \text { Belum tuntas }\end{array}$


Tabel 2. Rekapitulasi Hasil Tes Pada Siklus I

\begin{tabular}{llr}
\hline No & Uraian & $\begin{array}{r}\text { Hasil } \\
\text { Siklus I }\end{array}$ \\
\hline 1 & Nilai rata-rata tes formatif & 68,57 \\
2 & Jumlah siswa yang tuntas belajar & 8 \\
3 & Persentase ketuntasan belajar & 38,09 \\
\hline
\end{tabular}

Dari tabel di atas dapat dijelaskan bahwa dengan menerapkan Model kolaborasi diperoleh nilai rata-rata Hasil Belajar belajar siswa adalah 68,57 dan ketuntasan belajar mencapai 38,09\% atau ada 8 siswa dari 21 siswa sudah tuntas belajar. Hasil tersebut menunjukkan bahwa pada siklus pertama secara klasikal siswa belum tuntas belajar, karena siswa yang memperoleh nilai $\geq 75$ hanya sebesar $68,57 \%$ lebih kecil dari persentase ketuntasan yang dikehendaki yaitu sebesar $85 \%$. Hal ini disebabkan karena siswa masih merasa baru dan belum mengerti apa yang dimaksudkan dan digunakan guru dengan menerapkan Model kolaborasi.

\section{Siklus $N$}

\section{Tahap Perencanaan}

Pada tahap ini peneliti mempersiapkan perangkat pembelajaran yang terdiri dari rencana pelajaran 2, LKS 2, soal tes formatif 2 dan alat-alat pengajaran yang mendukung.

\section{Tahap Kegiatan dan Pengamatan}

Pelaksanaan kegiatan belajar mengajar untuk siklus $\mathrm{N}$ dilaksanakan sebanyak dua kali pertemuan. Dalam hal ini peneliti bertindak sebagai guru. Adapun proses belajar mengajar mengacu pada rencana pelajaran dengan memperhatikan revisi pada siklus I, sehingga kesalahan tidak terulang lagi pada siklus N. Pengamatan (observasi) dilaksanakan bersamaan dengan pelaksanaan belajar mengajar.

Pada akhir proses belajar mengajar siswa diberi tes formatif $\mathrm{N}$ dengan tujuan untuk mengetahui tingkat keberhasilan siswa dalam proses belajar mengajar yang telah dilakukan. Instrumen yang digunakan adalah tes formatif $\mathrm{N}$. Adapun data hasil penelitian pada siklus $\mathrm{N}$ adalah sebagai berikut.

Tabel 3. Distribusi Nilai Tes Pada Siklus N

\begin{tabular}{|c|c|c|c|c|c|c|c|}
\hline \multirow{2}{*}{$\begin{array}{l}\text { No. } \\
\text { Urut }\end{array}$} & \multirow{2}{*}{ Skor } & \multicolumn{2}{|c|}{ Keterangan } & \multirow{2}{*}{$\begin{array}{l}\text { No. } \\
\text { Urut }\end{array}$} & \multirow{2}{*}{ Skor } & \multicolumn{2}{|c|}{ Keterangan } \\
\hline & & $\mathrm{T}$ & TT & & & $T$ & TT \\
\hline 1 & 80 & $\sqrt{ }$ & & 12 & 70 & & $\sqrt{ }$ \\
\hline 2 & 90 & $\sqrt{ }$ & & 13 & 80 & $\sqrt{ }$ & \\
\hline 3 & 90 & $\sqrt{ }$ & & 14 & 100 & $\sqrt{ }$ & \\
\hline 4 & 60 & & $\sqrt{ }$ & 15 & 90 & $\sqrt{ }$ & \\
\hline 5 & 90 & $\sqrt{ }$ & & 16 & 90 & $\sqrt{ }$ & \\
\hline 6 & 90 & $\sqrt{ }$ & & 17 & 80 & $\sqrt{ }$ & \\
\hline 7 & 90 & $\sqrt{ }$ & & 18 & 90 & $\sqrt{ }$ & \\
\hline 8 & 80 & $\sqrt{ }$ & & 19 & 80 & $\sqrt{ }$ & \\
\hline 9 & 60 & & $\sqrt{ }$ & 20 & 100 & $\sqrt{ }$ & \\
\hline 10 & 80 & $\sqrt{ }$ & & 21 & 80 & $\sqrt{ }$ & \\
\hline 11 & 80 & $\sqrt{ }$ & & Jumlah & 860 & 9 & 1 \\
\hline Jumlah & 890 & 9 & 2 & & & & \\
\hline $\begin{array}{l}\text { Jumlah } \\
\text { Jumlah } \\
\text { Rata-Ra }\end{array}$ & $\begin{array}{l}\text { kor } 17 \\
\text { kor M } \\
\text { Skor }\end{array}$ & sim & $\begin{array}{l}\text { leal } 2 \\
83,33\end{array}$ & & & & \\
\hline
\end{tabular}

Keterangan:

$\mathrm{T}$

$$
\text { : Tuntas }
$$


TT

Jumlah siswa yang tuntas

Jumlah siswa yang belum tuntas

Klasikal
: Tidak Tuntas

$: 18$

$: 3$

: Tuntas

Tabel 4. Rekapitulasi Hasil Tes Pada Siklus N

\begin{tabular}{lll}
\hline No. & Uraian & Hasil Siklus N \\
\hline 1 & Nilai rata-rata tes formatif & 83,33 \\
2 & Jumlah siswa yang tuntas belajar & 18 \\
3 & Persentase ketuntasan belajar & 85,71 \\
\hline
\end{tabular}

Berdasarkan tabel di atas diperoleh nilai rata-rata tes formatif sebesar 83,33 dan dari 21 siswa yang telah tuntas sebanyak 18 siswa dan 3 siswa belum mencapai ketuntasan belajar. Maka secara klasikal ketuntasan belajar yang telah tercapai sebesar $85,71 \%$ (termasuk kategori tuntas). Hasil pada siklus $\mathrm{N}$ ini mengalami peningkatan lebih baik dari siklus $\mathrm{N}$. Adanya peningkatan hasil belajar pada siklus $\mathrm{N}$ ini dipengaeruhi oleh adanya peningkatan kemampuan guru dalam menerapkan belajar dengan Model kolaborasi sehingga siswa menjadi lebih terbiasa dengan pembelajaran seperti ini sehingga siswa lebih mudah dalam memahami materi yang telah diberikan.

\section{Refleksi}

Pada tahap ini akan dikaji apa yang telah terlaksana dengan baik maupun yang masih kurang baik dalam proses belajar mengajar dengan Penerapan model kolaborasi. Dari datadata yang telah diperoleh dapat diuraikan sebagai berikut:

1. Selama proses belajar mengajar guru telah melaksanakan semua pembelajaran dengan baik. Meskipun ada beberapa aspek yang belum sempurna, tetapi persentase pelaksanaannya untuk masing-masing aspek cukup besar.

2. Berdasarkan data hasil pengamatan diketahui bahwa siswa aktif selama proses belajar berlangsung.

3. Kekurangan pada siklus-siklus sebelumnya sudah mengalami perbaikan dan peningkatan sehingga menjadi lebih baik.

4. Hasil belajar siswa pada siklus $\mathrm{N}$ mencapai ketuntasan.

\section{Revisi Pelaksanaan}

Pada siklus $\mathrm{N}$ guru telah menerapkan belajar dengan Model kolaborasi dengan baik dan dilihat dari aktivitas siswa serta hasil belajar siswa pelaksanaan proses belajar mengajar sudah berjalan dengan baik. Maka tidak diperlukan revisi terlalu banyak, tetapi yang perlu diperhatikan untuk tindakan selanjutnya adalah memaksimalkan dan mempertahankan apa yang telah ada dengan tujuan agar pada pelaksanaan proses belajar mengajar selanjutnya penerapan model kolaborasi dapat meningkatkan proses belajar mengajar sehingga tujuan pembelajaran dapat tercapai.

Tabel 5. Perbandingan Persentase (\%) Hasil tes pada tiap siklus

\begin{tabular}{lllll}
\hline No. & Uraian & Hasil Siklus I & Hasil Siklus N & Peningkatan \\
\hline 1. & Nilai rata-rata tes formatif & $68,57 \%$ & $83,33 \%$ & $14,76 \%$ \\
2. & Jumlah siswa yang tuntas belajar & 8 & 8 & 10 \\
3. & Persentase ketuntasan belajar & $38,09 \%$ & $85,71 \%$ & $47,62 \%$ \\
\hline
\end{tabular}

Data pada tabel di atas menunjukkan perbandingan hasil tes siklus I dan siklus II. Nilai ratarata kelas pada tes siklus I mencapai 68,57 . Setelah penerapan model pengajaran kolaborasi dalam pembelajaran bahasa Indonesia pada siklus N, nilai rata-rata kelas menjadi 83,33 yang 
berarti mengalami peningkatan sebanyak 14,76. Data persentase ketuntasan belajar kelas juga mengalami peningkatan. Pada tes siklus I sebanyak $38,09 \%$ meningkat $47,62 \%$ pada siklus $\mathrm{N}$ menjadi $85,71 \%$.

\section{Pembahasan}

\section{Ketuntasan Hasil belajar Siswa}

Melalui hasil peneilitian ini menunjukkan bahwa model kolaborasi memiliki dampak positif dalam meningkatkan Hasil Belajar belajar siswa. Hal ini dapat dilihat dari semakin mantapnya pemahaman siswa terhadap materi yang disampaikan guru (ketuntasan belajar meningkat dari sklus I dan N) yaitu masing-masing $38,09 \%$, dan $85,71 \%$. Pada siklus $\mathrm{N}$ ketuntasan belajar siswa secara klasikal telah tercapai.

\section{Kemampuan Guru dalam Mengelola Pembelajaran}

Berdasarkan analisis data, diperoleh aktivitas siswa dalam proses pembelajaran dalam setiap siklus mengalami peningkatan. Hal ini berdampak positif terhadap Hasil Belajar belajar siswa yaitu dapat ditunjukkan dengan meningkatnya nilai rata-rata siswa pada setiap siklus yang terus mengalami peningkatan.

\section{Aktivitas Guru dan Siswa Dalam Pembelajaran}

Berdasarkan analisis data, diperoleh aktivitas siswa dalam proses pembelajaran pada pokok pembahasan dengan model kolaborasi yang paling dominan adalah mendengarkan/ memperhatikan penjelasan guru, dan diskusi antar siswa/ antara siswa dengan guru. Jadi dapat dikatakan bahwa aktivitas siswa dapat dikategorikan aktif.

Untuk aktivitas guru selama pembelajaran telah melaksanakan langkah-langkah belajar dengan model kolaborasi dengan baik. Hal ini terlihat dari aktivitas guru yang muncul di antaranya aktivitas membimbing dan mengamati siswa dalam mengerjakan kegiatan LKS/ menemukan konsep, menjelaskan, memberi umpan balik/ evaluasi/ tanya jawab dimana presentase untuk aktivitas di atas cukup besar.

\section{Kesimpulan}

Dari hasil kegiatan pembelajaran yang telah dilakukan selama dua siklus, dan berdasarkan seluruh pembahasan serta analisis yang telah dilakukan dapat disimpulkan bahwa pembelajaran dengan model kolaborasi memiliki dampak positif dalam meningkatkan hasil belajar siswa yang ditandai dengan peningkatan ketuntasan belajar siswa dalam setiap siklus, yaitu siklus | 68,57\%, siklus II 85,71\%. Penerapan model kolaborasi mempunyai pengaruh positif, yaitu dapat meningkatkan motivasi belajar siswa yang ditunjukan dengan rata-rata jawaban siswa hasil wawancara yang menyatakan bahwa siswa tertarik dan berminat dengn model kolaborasi sehingga mereka menjadi termotivasi untuk belajar.

Oleh karena itu, dari hasil penelitian yang diperoleh dari uraian sebelumnya agar proses belajar mengajar lebih efektif dan lebih memberikan hasil yang optimal bagi siswa, maka disarankan untuk melaksanakan belajar dengan model kolaborasi dengan persiapan yang cukup matang.

Dalam rangka meningkatkan Hasil Belajar siswa, guru hendaknya lebih sering melatih siswa dengan berbagai model atau metode, walau dalam taraf yang sederhana, dimana siswa nantinya dapat menemukan pengetahuan baru, memperoleh konsep dan keterampilan, sehingga siswa berhasil atau mampu memecahkan masalah-masalah yang dihadapinya. 


\section{Referensi}

Abdullah. (1997). Belajar dan Pembelajaran Bahasa Indonesia. Jakarta: Pusat Penerbitan Universitas Terbuka.

Abdurahhmad, M. (1996). Pendidikan Bagi Anak Berkualitas Belajar. Jakarta: Rineka Cipta.

Ali, M. (2000). Guru Dalam Proses Belajar Mengajar. Bandung: Sinar Baru.

Djamarah. (2002). Strategi Belajar Mengajar. Jakarta: PT. Rineka Cipta.

Dimayanti. (2000). Hakikat Pendekatan, Prosedur, dan Startegi Pembelajaran Bahasa Indonesia Berdasarkan Pendekatan Komunikatif dalam Sistem Pembelajaran Bahasa Indonesia (Modul UT), Jakarta: Pusat Penerbitan UT.

Haling, A. (2004). Belajar dan Pembelajaran. Makassar: FIP UNM Makassar Jamara. (1994) Metode Mengajar Efektif. Jakarta: Gramedia.

Kemmis, S. dan Mc. Taggart, R. (1988). The Action Research Planner: Victoria Dearcin University Press.

Hamalik, O. (2001). Kurikulum dan Pembelajaran. Jakarta: Bumi Angkasa

Rosestya, F. (1986). Analisis Belajar Bahasa. Jakarta. Erlangga 